\title{
Changes of plant cover of the raised peat-bog Baligówka under the influence of human activity
}

\author{
Zmiany szaty roślinnej torfowiska wysokiego \\ Baligówka pod wpływem działalności człowieka
}

*Drinż. Magdalena Malec, dr inż. Sławomir Klatka, dr hab. inż. Marek Ryczek dr inż. Edyta Kruk - Department of Land Reclamation and Environmental Development, Agriculture University of Krakow, Mickiewicza 24/28 St, 30-059 Krakow, Poland; phone: +48 1266240 15, e-mail: m.malec@ur.krakow.pl

Keywords: plant cover, phytosociological site record, succession, plant association, peat - bog vegetation, raised bogs Słowa kluczowe: szata roślinna, zdjęcia fitosocjologiczne, sukcesja, zbiorowiska roślinne, roślinność torfotwórcza, torfowisko wysokie

\begin{abstract}
The main purpose of the work was to determine the scope and degree of the influence of exploitation on changes of plant cover of the raised peat-bog Baligówka, located in the OrawskoNowotarska Valley. The analysis was carried out based on 47 phytosociological surveys using the Braun-Blanquet method. Results of investigations allow to state that excessive drying and fires that took place on the examined object caused wastage of many precious species of plants, especially from the OxycoccoSphagnetea class. Their place occupied species belonging to other classes, such as Nardo-Callunetea and Molinio-Arrhenatheretea. The basic cause of drying of the peat-bog and, in consequence, dying of peat formation species is intensified exploitation and connected with this drainage, carried out in the half of the 20th century. Unfortunately, local people up to now illegally have harvested the peat on the investigated object. Decrease in groundwater level leads to accelerated decay of peat, changes in physical and chemical properties of a substratum and, in consequence, changes in trophic values of habitat, what causes great changes in species composition of plant communities.
\end{abstract}

๑) IOŚ-PIB

\section{INTRODUCTION}

Function and perception of swamp areas, including peat-bogs have been diametrically changed during centuries. In the past, these areas had been recognised as wastelands and dangerous places. In later times, they became the source of the peat as fuel material, fertiliser, insulator and medicine. After had been exploited, they became grasslands or arable lands. At present, first of all, their ecological, hydrological, biocenotic and landscapeforming functions are taken into consideration [Kucharzyk and Szary 2012].

The main reason of degradation and disappearance of peat-bogs, apart from climatic changes, is their exploitation and connected with it drainage treatments. Disturbances of water conditions within peat-bog influence essentially on plant cover changes, consisting in expulsion of peat-forming species by communities

\section{Streszczenie}

Głównym celem niniejszej pracy było określenie zakresu i stopnia oddziaływania eksploatacji na zmiany szaty roślinnej torfowiska wysokiego Baligówka zlokalizowanego w Kotlinie Orawsko - Nowotarskiej. Analizę przeprowadzono na podstawie 47 zdjęć fitosocjologicznych wykonanych metodą Braun Blanqueta. Wyniki badań pozwalają stwierdzić, że nadmierne przesuszenie oraz pożary, jakie miały miejsce na badanym obiekcie, doprowadziły do zaniku wielu cennych gatunków roślin szczególnie z klasy Oxycocco - Sphagnetea. Ich miejsce zajmują gatunki należące do innych klas, takich jak Nardo - Callunetea oraz Molinio-Arrhenatheretea. Podstawową przyczyną przesuszenia torfowiska, a co za tym idzie również wymierania gatunków torfotwórczych jest intensywna eksploatacja oraz związane z nią odwodnienia, które zostały przeprowadzone w drugiej połowie XX wieku. Niestety okoliczna ludność do dnia dzisiejszego w sposób nielegalny pozyskuje torf na badanym obiekcie. Obniżenie poziomu wody prowadzi do przyśpieszonego rozkładu torfu, zmian właściwości fizycznych i chemicznych podłoża, a co za tym idzie trofii siedliska - to pociąga za sobą drastyczne zmiany w składzie gatunkowym zbiorowisk roślinnych.

of more broaden adaptable amplitude. It causes expansion of plants unfamiliar for those communities (amongst others, species belonging to classes Alneteaglutinosae, Epilobieteaangustifolii, Molinio-Arrhenatheretea and Nardo-Callunetea) and expulsion of peat-forming species, what essentially influences on dynamics of growth of acroterm layer of a peat-bog [Malec 2006, 2007, 2011]. Within a peat-bog ecosystems, more and more frequently, synanthropic processes take place. They consist in replacement of peat-bog-forming communities by unfamiliar species regarding both geography and habitat aspects [Jasnowskiet al. 1968, Gors 1969, Herbichowa 1976, Jasnowski 1972, Olesiński and Olkowski 1976, Polakowski 1976, Jasnowska and Jasnowski 1977]. The main purpose of the work is the determination of actual state of plant cover and the evaluation of stage and direction of 
changes taking place in plant communities on the raised peatbog Baligówka in the Orawsko-Nowotarska Valley under the influence of human activity.

\section{MATERIALS AND METHODS}

Investigations covered the raised peat-bog Baligówka located between Czarny Dunajec and Piekielnik in the OrawskoNowotarska Valley. This area consists the most precious complex of peat-bogs in the southern Poland. The object is located on lower terrace of the Czarny Dunajec cone, through the middle of dome courses European Watershed, what influences essentially on alimentation way [Łajczak, 2006]. Considering longlasting process of exploitation of this object, its area has been continuously decreased (since the 19th century, the area of the total peat-bog decreased from 335 up to 280 ha and the area of the dome from 235 up to 203 ha) [Lipka and Kosiński 1993, Łajczak 2006].

In the southern part, there is 35 ha of post exploitation field, where about 1.5-m layer of peat was removed and about $2 \mathrm{~m}$ was left. In spite of this, the area is highly dried and degraded - bare peat deposit is visible, quite deep ditches still drain off high amounts of water [Łajczak 2006].

Field investigations were carried out along transect of about 1,600 $\mathrm{m}$ (the total length of the object is $1,800 \mathrm{~m}$ ), coursing from south to north. Along the same transect, investigations concerning the determination of dynamics of growth of acroterm layer of peat were carried out [Malecet al. 2015]. Investigations covered both post exploitation and without exploitation areas.

For the characteristics of actual state of plant cover, 47 phytosociological surveys were made using the Braun-Blanquet method. Every survey had dimension of $25 \mathrm{~m}^{2}$. Data were presented in tables; for particular species, stability state was calculated and phytosociological attachment was determined [Matuszkiewicz 2005, Wysocki and Sikorski 2009].

\section{RESULTS}

On the area of the peat-bog Baligówka, 47 phytosociological surveys were made, in which 36 species were distinguished. Most, as many as 11 were classified to the class OxycoccoSphagnetea, the second one regarding numbers is the class Vaccinio-Piceetea with seven species. They are two dominant classes. Apart from these on the peat-bog, characteristics species for the classes: Molinio-Arrhenatheretea (four species), NardoCallunetea (three species) and Scheuchzerio-Cariceteanigrae (four species) were found - but they are less numerous and do not make correctly developed communities. Remaining seven species of plants were classified to so-called concurrent species, because they cannot be classified to any of the mentioned above classes (Table 1).

The class Oxycocco-Sphagnetea is under shrub-peat moss community of wet moors and raised bogs of characters of acid habitats fed by precipitation oligotrophic water [Matuszkiewicz 2005]. This class is represented by 11 plants classified into 2 associations: Sphagnetum magellanici and Pino mugoSphagnetum. The characteristics species for these associations are Eriophorum vaginatum, Sphagnum rubellum, Sphagnum magellanicum and Aulocomnium palustre. Within this class, the highest stability degree, amounted $\mathrm{V}$, is characterised by two species, E. vaginatum and Oxycoccus palustris, and a little lesser (IV) with one species, S. rubellum - for remaining species, the stability degree is much more lower. In local depressions, one can find several species of peat moss: S. rubellum (IV), Sphagnum fuscum (II), Sphagnum recurvum (II) and S. magellanicum (I) and one species of brown moss, A. palustre (I). Within 10 phytosociological surveys, the presence of Drosera rotundifolia - species that very seldom settling wet and good and sun-heated areas - was stated (4 surveys were characterised by quite high degree of cover by regarded species (Table 1).

The second class regarding numbers and occupied area is the class Vaccinio-Piceetea, particularly the association Vacciniouliginosi-Pinetum. Appearance of continental marshy coniferous forest may testify high anthropogenic influence (drainage and exploitation) or natural process of succession in a direction of pine coniferous forest, that is, a result of the end of growth and development of raised bog. In case of the investigated object, there is characteristic high influence of human activity, which caused excessive drying of the habitat. In the regarded community, the highest cover degree has Pinus sylvestris, V, and Ledum palustre, IV. The remaining species characteristics for marshy coniferous forest occurring within surveys have lower stability degree from III to I (Table 1). On dried raised peat-bogs, it is quite difficult to distinguish between associations Vacciniouliginosi-Pinetum and Ledo-Sphagnetum magellanici - this division is mainly based on quantitative hold of typically coniferous forests species (in this case, P. sylvestris, Pinus xrhaetica and Vaccinium uliginosum).

On the peat-bog Baligówka, occurrence as well as plant species characteristics for three other classes were stated: Molinio-Arrhenatheretea, Nardo-Callunetea and ScheuchzerioCariceteanigrae; however, they do not create correctly developed communities. Scheuchzerio-Cariceteanigrae is the community characteristics amongst others for lowland and transitional bogs and valley phase of raised bogs [Matuszkiewicz, 2005]. On the investigated object, it is represented by four species: Eriophorum angustifolium, Sphagnum cuspidatum, Carex nigra and Carex panicea. Occurrence of two remaining classes, MolinioArrhenatheretea and Nardo-Callunetea, testify great changes, which took place in the investigated ecosystems under influence of human activity.

Molinio-Arrhenatheretea has anthropogenic character composes mainly meadow and pasture communities covering not bogginess mineral or organic-mineral soils and dried peat earth of lowland bogs [Matuszkiewicz 2005]. All the four species belonging to this class are characterised by low stability degree. The next distinguished unit is Nardo-Callunetea. They are seminatural and anthropogenic communities of white bent and moor sward. Their appearance especially on the swamp areas testify high drying and degradation of habitat. In this class, the highest cover degree (V) has Calluna vulgaris - species characteristics for the order Calluno-Ulicetalia, that is, communities created under the influence of pasture human activity. C. vulgaris and $E$. vaginatum (in a case of this species, such abundance is very advantageous) 


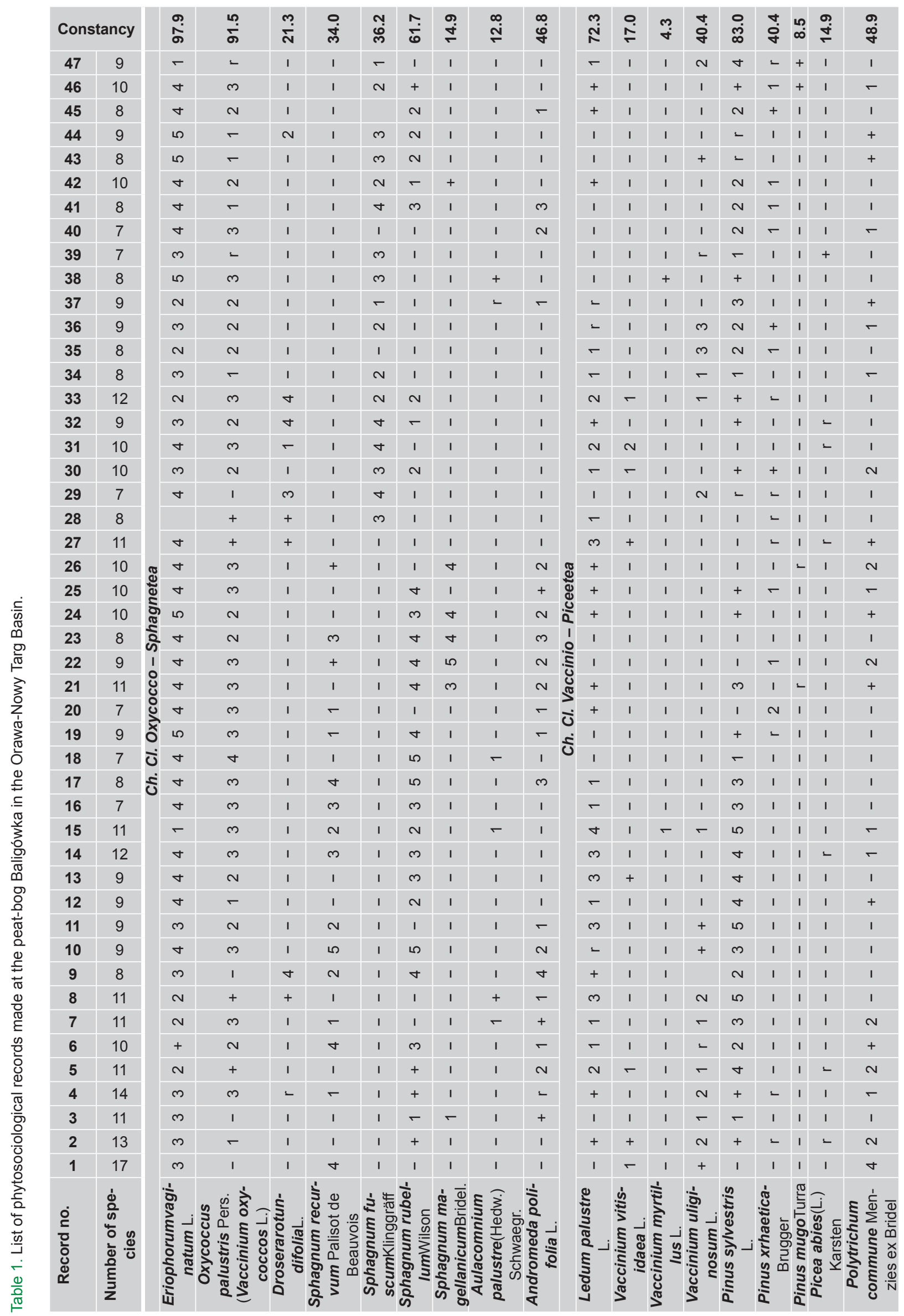




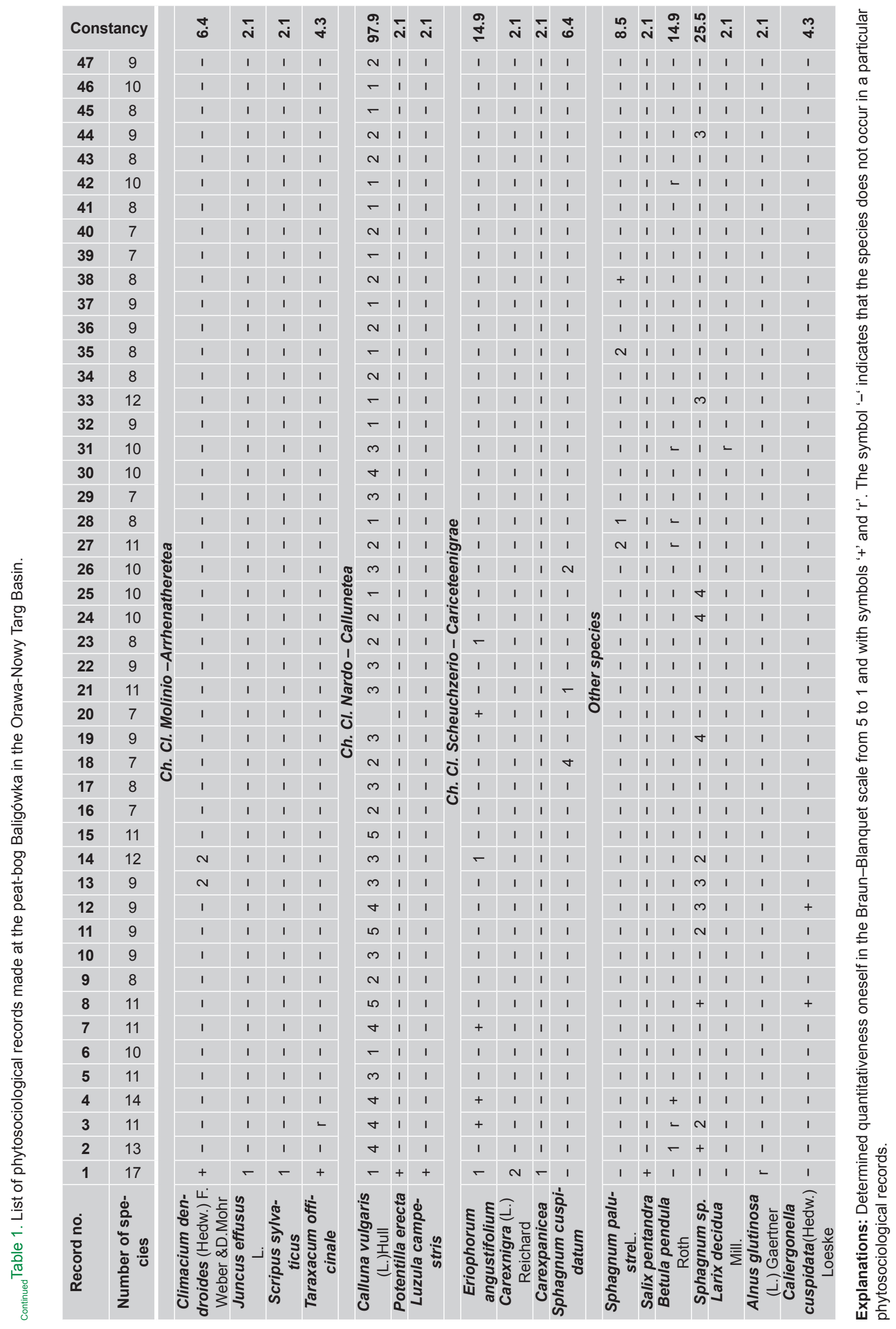


are species of the highest cover degree amounting about $98 \%-$ in the both cases, amongst 47 surveys, only in 1 case, they were not stated.

On the investigated area, seven species that cannot be classified to any of the above classes were stated - they were described as concurrent species.

During field investigations, quite great amount of old drainage ditches was stated, which in spite of overgrowing by plant, mainly moss, drain off great amount of water. In the northern part of the object, several places testifying not legal exploitation of peat by local people (post peat pits) were stated. In the southern part, clearly visible post exploitation scarp occurs. In this part of the object, human activity is visible in a shape of old exploitation field of 35 ha area. Great area of open peat (at present highly degraded) and higher percentage of tree plants and undershrub $C$. vulgaris testify to that - phytosociological surveys $1-19$ (Table 1 ).

\section{CONCLUSIONS}

1. The investigations of actual state of plant cover on the peat-bog Baligówka showed that the dominant classes are: Oxycocco-Sphagnetea and Vaccinio-Piceetea.

\section{REFERENCES}

GORS S. 1969. Der Wandel der Vegetation imNaturchutzgebietSchweninger Moos unterdemEinfluss des Menschen in zweiJahrhunderten. - Die Nat. U. Landschaftschutzgebiete Bad.-Wurtt. 5: 190-284.

HERBICHOWA M. 1976. Zanikanie gatunków na przykładzie atlantyckich torfowisk Pobrzeża kaszubskiego. Phytocoenosis 5, 3/4: 247-254.

JASNOWSKA J., JASNOWSKI M. 1977. Zagrożone gatunki flory torfowisk. - Chrońmy Przyr. Ojcz. 33, 4: 5-14.

JASNOWSKI M. 1972. Rozmiary i kierunki przekształceń szaty roślinnej torfowisk. - Chrońmy Przyr. Ojcz. 33, 4: 5-14.

JASNOWSKI M., JASNOWSKA J., MARKOWSKI S. 1968. Ginące torfowiska wysokie i przejściowe w pasie nadbałtyckim Polski. - Ochr. Przyr. 33: 69-124.

KUCHARZYK S., SZARYA. 2012. Degradacja i ochrona torfowisk wysokichw Bieszczadzkim Parku Narodowym, ROCZNIKI BIESZCZADZKIE 2012, 20: 83-97.

LIPKA K., KOSIŃSKI K. 1993. Torfowiska w okolicy Czarnego Dunajca na tle sieci hydrograficznej. [W:] Melioracje terenów górskich a ochrona środowiska, Sesja Naukowa z okazji 100lecia uniwersyteckich studiów rolniczych w Polsce, Kraków 25.06.1990, AR w Krakowie, 197-207.

ŁAJCZAK A. 2006. Torfowiska Kotliny Orawsko - Nowotarskiej. Rozwój, antropogeniczna degradacja, renaturyzacja i wybrane problemy ochrony. Instytut Botaniki PAN Kraków.
2. Occurrence of characteristics species for the class VaccinioPiceetea, such as V. uliginosum, $P$. sylvestris and Ledum palustre, testify to deterioration of water conditions, being the effect of previous human activity. It led to acceleration of succession in a direction of marshy coniferous forest.

3. The phenomenon testifying to degradation of peat forming plant communities is occurrence of species characteristics for the classes: Molinio-Arrhenatheretea and NardoCallunetea. It is possible that their presence is connected not only with drying of the object, but as well as is a result of diaspore brought by people penetrating the object.

4. Mass occurrence of species $P$. sylvestris and $C$. vulgaris is a result of high drying and anthropogenic degradation of the peat-bog Baligówka.

5. For restraint of further degradation of the investigated object it is necessary to undertake activities consisting in stopping outflow of water from the dome and restoration of primary plant communities.

MALEC M. 2006. Dynamika wzrostu torfowisk wysokich w Bieszczadach Zachodnich. Praca doktorska, AR Kraków (maszynopis).

MALEC M. 2007. Aktualny stan szaty roślinnej trzech wybranych torfowisk wysokich w Bieszczadach Zachodnich. Parki Nar. Rez. Przyr. 26, 3: 33-47.

MALEC M. 2011. Stan aktualny i antropogeniczne przekształcenia ekosystemu torfowiska Puścizna Długopole w Kotlinie Orawsko-Nowotarskiej. Ochrona Środowiska i Zasobów Naturalnych 49: 548-558.

MALEC M., KLATKA S., RYCZEK M. 2015. Wpływ antropopresji na dynamikę wzrostu warstwy akrotelmowej na torfowisku wysokim Baligówka w Kotlinie Orawsko-Nowotarskiej, Acta Sci. Pol., FormatioCircumiectus 14, 1: 149-160.

MATUSZKIEWICZ W. 2005. Przewodnik do oznaczania zbiorowisk roślinnych Polski. PWN, Warszawa.

OLESIŃSKI L., OLKOWSKI M. 1976. Zanikanie niektórych gatunków torfowiskowych roślin naczyniowych w północnowschodniej Polsce. - Phytocoenosis 53, 4: 255-264.

POLAKOWSKI B.1976. Zanikanie składników torfowiskowych na Pojezierzu Mazurskim. - Phytocoenosis 5, 3/4: 265-274.

WYSOCKI C., SIKORSKI P. 2009. Fitosocjologia stosowana w ochronie i kształtowaniu krajobrazu. SGGW 2009. 